\title{
Proses Kematangan Emosi pada Individu Dewasa Awal yang Dibesarkan dengan Pola Asuh Orang Tua Permisif
}

\author{
DINA RAHMA ADILA \& AFIF KURNIAWAN*
}

Departemen Psikologi Klinis dan Kesehatan Mental, Fakultas Psikologi Universitas Airlangga

\begin{abstract}
ABSTRAK
Penelitian ini bertujuan untuk mendapatkan gambaran proses kematangan emosi individu dewasa awal yang dibesarkan dengan pola asuh orang tua permisif dilihat dari manifestasi kematangan emosi dan faktor-faktor yang memengaruhi proses kematangan emosi individu. Kematangan emosi termanifestasi melalui tiga dimensi yaitu kontrol emosi, pemahaman diri, dan fungsi kritis mental serta dipengaruhi faktor individu, lingkungan dan pengalaman dalam proses pencapaiannya. Penelitian ini menggunakan metode kualitatif dengan teknik studi kasus intrinsik yang melibatkan empat individu dewasa awal. Teknik penggalian data menggunakan wawancara kualitatif dengan pedoman umum. Teknik analisis data menggunakan metode analisis tematik yang theory-driven. Pemantapan kredibilitas penelitian dilakukan dengan member check. Hasil penelitian menunjukkan pola asuh orang tua permisif berdampak pada proses kematangan emosi individu dewasa awal baik secara positif maupun negatif, ditandai dengan keadaan serta pengelolaan emosi yang terganggu, proses pencapaian pemahaman diri yang terbangun dari faktor di luar keluarga, dan fungsi kritis mental yang berkembang.
\end{abstract}

Kata kunci: dewasa awal, kematangan emosi, pola asuh permisif

\begin{abstract}
This study aims to get a picture of the emotional maturity process of early adult individuals who are raised with permissive parenting as seen from the manifestations of emotional maturity and the factors that influence the emotional maturity process of individuals. Emotion maturity is manifested through three dimensions, namely emotional control, self-understanding, and critical mental functions and is influenced by individual factors, the environment and experience in the process of achieving it. This study uses a qualitative method with an intrinsic case study technique involving four early adult individuals. Data mining techniques used qualitative interviews with general guidelines. The data analysis technique uses a theory-driven thematic analysis method. Strengthening research credibility is done by member checking. The results showed permissive parenting has an impact on the emotional maturity process of early adult individuals both positively and negatively, marked by disturbed emotional conditions and management, the process of achieving self-understanding that is built from factors outside the family, and mental critical functions that develop.
\end{abstract}

Key words: early adult, emotional maturity, permissive parenting 
INSAN Jurnal Psikologi dan Kesehatan Mental, 2020, Vol. 5(1), 21-34, doi: 10.20473/jpkm.v5i12020.21-34 Dikirimkan: 30 Januari 2020 Diterima: 1 Mei 2020 Diterbitkan: 26 Juni 2020

Editor: Rizqy Amelia Zein

*Alamat korespondensi: Fakultas Psikologi Universitas Airlangga, Kampus B Universitas Airlangga Jalan Airlangga 4-6 Surabaya 60286. Pos-el: afif.kurniawan@psikologi.unair.ac.id

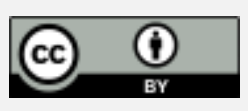

Naskah ini merupakan naskah dengan akses terbuka dibawah ketentuan the Creative Common Attribution License (http://creativecommons.org/licenses/by/4.0), sehingga penggunaan, distribusi, reproduksi dalam media apapun atas artikel ini tidak dibatasi, selama sumber aslinya disitir dengan baik.

\section{P E N D A H U L U A N}

Dewasa awal merupakan suatu masa di mana individu memiliki fisik dan optimisme yang berada dalam kondisi optimal namun sekaligus penuh tekanan serta memikul risiko tinggi akan kerentanan sosial dan perkembangan (Kuwabara, dkk., 2007). Dewasa awal merupakan masa perkembangan yang kompleks yang menyangkut asumsi mengenai peran orang dewasa dengan proses psikologis yang mendasarinya (Shulman, dkk., 2005). Masa dewasa awal merupakan masa di mana individu melalui periode perkembangan yang unik (Arnett, 2000, dalam Kilic, dkk., 2015). Individu yang memasuki masa dewasa akan mengalami perubahan dan penyesuaian sosial serta psikologis sehingga dapat memunculkan kebingungan dan ketidaknyamanan. Hal ini disebabkan oleh pergantian peran lama serta penyesuaian nilai-nilai yang dipegang sebelumnya untuk kemudian dievaluasi kembali, disesuaikan, atau bahkan dilepaskan (Matt, Seus, \& Schumann, 1997, dalam Shulman, dkk., 2005).

Terdapat beberapa kemungkinan dari pemisahan tugas-tugas perkembangan praktis dan psikologis pada masa dewasa awal yang dapat berdampak pada pembentukan identitas, pengaturan diri, serta pengembangan makna personal individu mengenai remaja dan asumsinya mengenai peran orang dewasa (Sherrod, 1996, dalam Shulman, dkk., 2005). Individu dewasa awal telah menyelesaikan tahap pertumbuhannya sehingga siap berbaur menjalani kehidupan bermasyarakat bersama-sama dengan orang dewasa lainnya (Hurlock, 1999). Individu dewasa awal memiliki tuntutan berupa tugas perkembangan yang harus dipenuhi, yaitu bekerja, memilih pasangan, membina keluarga, mengasuh anak, mengelola rumah tangga, mengambil tanggung jawab sebagai warga negara, dan mencari kelompok sosial yang menyenangkan (Hurlock, 2004).

Pengalaman yang melibatkan pembelajaran emosional, baik pengalaman buruk maupun pengalaman menyenangkan, merupakan bentuk dari pembelajaran yang menjadi bagian dari proses perkembangan (Nelson, dkk., 2014). Berdasarkan studi fungsi kognitif yang dilakukan oleh Yurgelun-Todd (2007), perkembangan otak dan respon fisiologis individu terus berubah selama masa anak-anak, masa remaja, hingga masa dewasa awal. Permasalahan mengenai pengelolaan fungsi emosional pada masa anak-anak berkorelasi dengan kondisi korteks asosiasi posterior dan frontal yang belum matang. Hubungan sosial pada masa remaja kemudian membantu anak dalam mengembangkan fungsi emosionalnya dengan meningkatkan kemampuan mengatur respon afektif serta membaca isyarat sosial dan emosional. Ketika memasuki masa dewasa, kemampuan anak dalam memperhatikan informasi meningkat sehingga anak dapat mencapai tujuan sembari memiliki kendali penuh atas perilakunya.

Penelitian ini bertujuan untuk mengetahui gambaran proses kematangan emosi pada individu dewasa awal yang dibesarkan dengan pola asuh permisif meliputi manifestasi kematangan emosi dan faktorfaktor yang memengaruhi proses pencapaian kematangan emosi individu dewasa awal yang dibesarkan dengan pola asuh permisif. Penelitian kualitatif yang membahas tentang proses kematangan emosi INSAN Jurnal Psikologi dan Kesehatan Mental Tahun 2020, Vol. 5(1), 21-34 
masih belum ditemukan di Indonesia sehingga mendorong penulis untuk melakukan penelitian. Penelitian mengenai kematangan emosi masih banyak terfokus pada remaja sebagai subjek. Hal ini dikarenakan remaja merupakan periode kritis sebagai masa transisi dari masa anak-anak menuju masa dewasa yang mendasari perkembangan fungsi kognitif, sosial, dan emosional (Yurgelun-Todd, 2007). Individu yang seharusnya memiliki kematangan emosi yang baik adalah individu yang telah mencapai masa dewasa, padahal masih banyak faktor yang menghambat individu dewasa untuk mencapai tingkat kematangan emosi yang baik, yaitu salah satunya adalah pola asuh yang tidak tepat seperti yang telah dipaparkan sebelumnya.

\section{Kematangan Emosi}

Kematangan emosi merupakan keseimbangan antara emosi dengan otak serta antara dunia dalam dengan dunia luar individu. Individu tidak dapat mencapai realisasi intelegensi seutuhnya jika memiliki kematangan emosi yang rendah (Landau, 1998). Kematangan emosi menurut Yusuf (2001) ialah kemampuan bersikap toleran dan merasa nyaman dengan diri sendiri, serta kemampuan mengontrol diri dan memiliki perasaan menerima diri sendiri serta orang lain, dan juga kemampuan individu untuk mampu menyatakan emosi secara konstruktif sekaligus kreatif. Benokraitis (1996, dalam Khairani \& Putri, 2011) mengungkapkan bahwa bertambahnya usia individu seiring dengan bertambahnya kemampuan kontrol emosi serta tingkat kematangan emosinya. Namun merujuk pada pemaparan Walgito (2002), pertambahan usia seseorang bertambah tidak selalu beriringan dengan matangnya kemampuan pengelolaan emosi, walaupun memang diharapkan bahwa kematangan emosi akan semakin baik jika dikaitkan dengan pertambahan usia seseorang.

Individu dengan usia yang matang atau dewasa secara kronologis sangat mungkin untuk memiliki tingkat kematangan emosi yang rendah. Pertambahan usia dan tingkat kematangan emosi individu berjalan beriringan, namun individu yang matang secara usia dan fisik belum tentu secara otomatis matang secara emosi (Young, 2007, dalam Khairani \& Putri, 2011). Kematangan emosi tidak lepas dari faktor-faktor yang memengaruhi proses pencapaiannya. Faktor lingkungan seperti pola asuh orang tua sebagai lingkungan individu menjalani kehidupannya menjadi salah satu faktor yang memengaruhi kematangan emosi. Selain itu, faktor internal individu seperti tempramen beserta karakteristik emosi, usia, dan jenis kelamin, serta faktor pengalaman seperti trauma juga dapat memengaruhi kematangan emosi individu (Astuti, 2000).

Kematangan Emosi termanifestasi dalam tiga dimensi (Hurlock, 2004), yaitu:

\section{Kontrol Emosi}

Individu yang matang secara emosi dapat mengelola emosi dan juga ekspresi dari emosinya dengan baik. Ia juga dapat mengatur kapan dan bagaimana emosinya akan dimanifestasikan, meski sedang dalam kondisi emosi yang buruk (Walgito, 2002). Ketika menemui kegagalan, individu yang matang secara emosi memiliki kemampuan untuk menghadapi rasa frustrasi dan akan mencoba mencari jalan keluar dan bukan hanya meratapi nasibnya. Ketika berhadapan dengan masalah, individu memiliki kemampuan untuk menangani permusuhan secara konstruktif dan tidak akan berusaha menyalahkan orang lain sehingga memunculkan permusuhan. Individu yang matang secara emosi relatif terbebas dari ketegangan emosional, cenderung santai serta percaya diri dalam mengatasi masalah dan tetap menghadapi kenyataan (Murray, 1997).

2. Pemahaman Diri 
Individu yang matang secara emosi mampu menerima kondisi diri sendiri dan orang lain menurut keadaan yang sebenarnya (Walgito, 2002). Hal ini juga dikarenakan individu memahami emosi diri sendiri dengan memahami hal yang sedang dirasakan serta mengetahui penyebab dari emosi tersebut. Individu memiliki kemampuan untuk memberi dan menerima kasih sayang, yang mengindikasikan bahwa ia mampu menumbuhkan rasa aman terhadap hubungan interpersonal maupun intrapersonal. Hal ini berarti ia tidak memungkiri bahwa manusia itu rentan dan memiliki kelemahan, sehingga ia tidak merasa perlu untuk menutupinya dan tidak ragu untuk mengungkapkan serta menerima ungkapan cinta dengan orang lain. Sehingga dalam hal lain, individu yang belum matang secara emosi dapat menjadi egosentris dengan hanya ingin menerima cinta tanpa mampu mengenali kebutuhan orang lain untuk menerima cinta (Murray, 1997).

Individu akan mampu merasakan kesenangan bukan hanya saat menerima tapi juga saat memberi, hal ini dikarenakan ia menyadari bahwa kehidupan berjalan seimbang dan bergantian. Hal ini juga dapat berarti bahwa individu memiliki empati yang baik. Individu akan merasa bahwa orang lain juga berhak untuk merasakan kesenangan yang sama seperti dirinya, serta individu akan memiliki keinginan untuk meningkatkan kualitas hidup orang-orang yang ia cintai. Maka dari itu, individu akan turut merasakan kesenangan saat memberi atau berbagi, dan sebaliknya, ia juga mampu menerima pemberian dari orang lain dan merasa senang (Murray, 1997).

Individu mampu memandang dan memahami pengalaman hidup secara positif. Individu akan memandang pengalaman hidup sebagai pembelajaran dan upaya untuk memahami diri serta kehidupannya dengan lebih baik. Ia mampu bergembira ketika keadaan sedang baik dan ketika keadaan sedang buruk mereka mampu mengambil hikmah. Selain itu, individu juga mempu belajar dari pengalaman, ia akan menyimpan pengetahuan baru dari pengalaman positif dan mampu mencari celah untuk dapat belajar dari pengalaman negatif untuk menjadi pribadi yang lebih baik dan mencapai kehidupan yang lebih baik (Murray, 1997).

\section{Penggunaan Fungsi Kritis Mental}

Individu yang matang secara emosi tidak bersifat impulsif, namun dapat mengatur pikirannya dengan baik dan bertindak rasional serta merespon stimulus dengan tepat. Individu juga dapat berpikir secara objektif dan memiliki toleransi dan pengertian yang baik terhadap berbagai hal. Selain itu, individu memiliki tanggung jawab yang baik, mandiri, dan menghadapi masalah dengan bijak (Walgito, 2002). Individu memiliki kemampuan untuk menghadapi dan menerima kenyataan. Tingkat kedewasaan individu dapat dilihat dari sejauh mana individu menghadapi atau menghindari masalah. Individu yang matang secara emosi akan mencari cara tercepat untuk mencari jalan keluar dari masalahnya dan berusaha untuk segera menyelesaikannya tanpa menunda-nunda (Murray, 1997).

\section{Pola Asuh Orang Tua Permisif}

Peran orang tua dalam pengasuhan serta interaksi antar anggota keluarga merupakan faktor penting yang memengaruhi perkembangan emosional anak (Eisenberg, dkk., 1998, dalam Kilic, dkk., 2015). Shulman, dkk. (2005) dalam penelitiannya mengungkapkan bahwa self-organization dalam pemenuhan tugas perkembangan dewasa awal berkaitan dengan hubungan individu dan orang tuanya. Orang tua memiliki peranan krusial dalam masa penyesuaian anak memasuki masa dewasa awal, terutama mengenai permasalahan pengelolaan emosi individu pada masa dewasa awal sebagai periode perkembangan yang unik (Kilic, dkk., 2015). Selain itu, pengalaman buruk pada masa anak-anak menimbulkan banyak permasalahan klinis yang berdampak pada kesehatan mental individu, baik pada INSAN Jurnal Psikologi dan Kesehatan Mental Tahun 2020, Vol. 5(1), 21-34

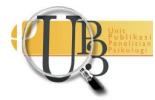


masa anak-anak maupun ketika memasuki masa dewasa (Schilling, dkk., 2007). Sikap orang tua dalam pengasuhan memengaruhi kemampuan pengelolaan emosi individu pada masa dewasa awal (Kilic, dkk., 2015). Pola asuh yang diterapkan orang tua berdampak pada karakter anak ketika dewasa (Anisah, 2017). Peran orang tua dalam menerapkan pola asuh menjadi demikian krusial. Dengan menerapkan pola asuh yang tidak tepat, anak dapat tumbuh menjadi individu dengan pola perilaku yang bermasalah (Rakhmawati, 2015). Salah satu pola asuh yang sarat dinamika dan masalah menurut penelitianpenelitian terdahulu adalah pola asuh permisif. Pola asuh permisif digambarkan Bee \& Boyd (2007, dalam Rahmawan, 2013) sebagai pola asuh di mana orang tua juga tidak memberikan batasan, tuntutan, serta kontrol, dan juga memiliki komunikasi yang kurang antara anak dan orang tua.

Maccoby \& Martin (1983, dalam Baumrind, 1991) membagi pola asuh orang tua menjadi dua dimensi, yaitu:

1. Tanggapan (Responsiveness)

Tanggapan orang tua mengacu pada dukungan dan penerimaan orang tua terhadap aspirasi, kebutuhan, dan keinginan anak, membangun relasi yang hangat, membuka komunikasi dua arah (Baumrind, 1991).

\section{Tuntutan (Demandingness)}

Tuntutan orang tua mengacu pada pengendalian perilaku anak oleh orang tua, di mana orang tua menetapkan standar dan berupaya untuk membuat anak patuh dan disiplin terhadap aturan-aturan orang tua, termasuk dengan melakukan pengawasan, dan perlakuan ketika anak melakukan kesalahan atau pelanggaran (Baumrind, 1991).

Baumrind (1971, dalam Santrock, 1991) membagi pola asuh permisif atau laissez-faire menjadi dua macam, yaitu:

a. Permisif-abai

Pola asuh orang tua permisif-abai memiliki tanggapan (responsiveness) dan tuntutan (demandingness) yang sama-sama rendah terhadap anak. Orang tua memberikan pengawasan dan tuntutan yang sangat rendah terhadap anak serta mengabaikan peran pengasuhan mereka (Baumrind, 1991). Orang tua sangat tidak terlibat dalam kehidupan anak. Orang tua menyerahkan semua keputusan kepada anak serta tidak menerapkan aturan atau larangan apapun. Orang tua membuat anak merasa kehidupan orang tua lebih penting daripada diri anak (Baumrind, 1971 dalam Santrock, 1991).

b. Permisif-menuruti

Pola asuh orang tua permisif-menuruti memiliki tanggapan (responsiveness) yang tinggi namun tuntutan (demandingness) yang rendah terhadap anak. Orang tua dengan pola asuh ini cenderung mendukung atau menuruti semua keinginan anak. Mereka sangat toleran terhadap segala perilaku anak, dan cenderung tidak peduli meskipun anak mengembangkan perilaku yang tidak terpuji (Baumrind, 1991). Orang tua sangat terlibat dengan anak namun tidak menerapkan tuntutan, batasan, dan kontrol apapun. Mereka membiarkan anak melakukan semua yang ia inginkan dan tidak menerapkan larangan apapun. Orang tua selalu menuruti semua keinginan dan membiarkan segala bentuk perilaku anak dan tidak pernah memberikan larangan atau penolakan kepada anak. Beberapa orang tua sengaja menerapkan pola asuh ini dan memiliki keyakinan bahwa kombinasi antara keterlibatan yang hangat dengan sedikit batasan akan mengembangkan rasa percaya diri dan kreativitas anak (Baumrind, 1971, dalam Santrock, 1991). 


\section{ME T O D E}

\section{Desain Penelitian}

Tipe penelitian yang digunakan dalam penelitian ini adalah penelitian kualitatif dengan jenis penelitian studi kasus intrinsik. Metode ini digunakan dengan tujuan untuk dapat mendalami subjek baik individu maupun kelompok yang mengalami kasus tertentu dan menggali secara detail mengenai latar belakang, sifat-sifat, dan karakter khas dari kasus ataupun status subjek tersebut serta lebih terfokus pada peristiwa saat ini dan tidak perlu untuk menerapkan suatu kontrol atas perilaku subjek (Poerwandari, 2007; Yin, 2011). Peneliti menggunakan pendekatan studi kasus intrinsik dalam penelitian ini dengan tujuan memahami berbagai fakta secara utuh mengenai gambaran proses kematangan emosi pada individu dewasa awal yang dibesarkan dengan pola asuh orang tua permisif. Dengan begitu, pemahaman tersebut dapat turut memberi pengetahuan baru serta masukan yang berguna terhadap masalah yang ada.

\section{Partisipan}

Subjek dalam penelitian ini adalah empat individu dewasa awal berusia 21-39 tahun (Santrock, 2010) yang dibesarkan dengan pola asuh orang tua permisif, yaitu dalam pengasuhannya menerima tanggapan, aturan, tuntutan, larangan, dan hukuman yang minim (Baumrind, 1991).

\section{Teknik Penggalian Data}

Penggalian data dalam penelitian ini menggunakan teknik wawancara kualitatif yang mengacu pada pedoman penelitian yang terstruktur namun tidak terlalu kaku dan terpaku pada daftar pertanyaan tertutup, sehingga memungkinkan peneliti untuk mengembangkan interaksi dengan subjek melalui komunikasi dua arah sehingga memungkinkan subjek untuk dapat mengungkapkan pengalaman atau pendapatnya secara apa adanya dan membuat pemaknaan informasi lebih luas dan mendalam (Yin, 2011).

\section{Analisis Data}

Teknik pengorganisasian dan analisis data dalam penelitian ini menggunakan analisis tematik dengan pendekatan theory-driven. Analisis tematik theory-driven dilakukan dengan menyusun pengidentifikasian tema-tema yang terpola dalam suatu fenomena yang dilakukan berdasarkan teori atau kode yang sudah ada (Boyatzis, 1998). Penulis melakukan member checking untuk meningkatkan kredibilitas penelitian, yaitu dengan melakukan wawancara lebih lanjut dengan subjek dengan tujuan agar subjek dapat mengklarifikasi hasil penelitian yang telah dilakukan. Data penelitian yang telah dianalisis akan diberikan kembali pada subjek agar dapat diperiksa sehingga peneliti dan subjek memiliki pemahaman dan interpretasi yang sama terhadap hasil penelitian (Creswell, 2007). 
HAS IL PENELITIAN

Tabel 1. Hasil Penelitian

\begin{tabular}{|c|c|c|c|c|}
\hline \multirow{2}{*}{$\begin{array}{l}\text { Partisipan } \\
\text { Penelitian }\end{array}$} & \multicolumn{3}{|c|}{ Kematangan Emosi } & \multirow{2}{*}{$\begin{array}{c}\text { Faktor } \\
\text { Pendukung \& } \\
\text { Penghambat } \\
\text { Kematangan } \\
\text { Emosi }\end{array}$} \\
\hline & $\begin{array}{c}\text { Kontrol } \\
\text { Emosi }\end{array}$ & $\begin{array}{c}\text { Pemahaman } \\
\text { Diri }\end{array}$ & $\begin{array}{l}\text { Fungsi Kritis } \\
\text { Mental }\end{array}$ & \\
\hline $\begin{array}{c}\text { Partisipan } \\
1\end{array}$ & $\begin{array}{l}\text { Masalah Emosi: } \\
\text {-Depresif } \\
\text {-Moodswings } \\
\text {-Mudah tersinggung } \\
\text { Saat lebih menerima } \\
\text { dirinya, baik secara } \\
\text { emosi maupun } \\
\text { kondisi sehingga } \\
\text { tidak berusaha } \\
\text { menekan emosinya } \\
\text { serta sudah tidak } \\
\text { terlarut dalam emosi } \\
\text { negatif. }\end{array}$ & $\begin{array}{l}\text { Pemahaman diri } \\
\text { yang buruk } \\
\text { karena sulit } \\
\text { mengembangkan } \\
\text { empati. } \\
\text { Pemahaman diri } \\
\text { diperoleh dari } \\
\text { teman, diskusi, } \\
\text { dan upaya } \\
\text { mendengarkan } \\
\text { orang lain. } \\
\text { Mendapatkan } \\
\text { pemahaman } \\
\text { bahwa emosi } \\
\text { negatifnya harus } \\
\text { ia terima sebagai } \\
\text { bagian dari } \\
\text { dirinya yang } \\
\text { harus ia cintai. } \\
\text { Masalah } \\
\text { Insecurity. }\end{array}$ & $\begin{array}{l}\text { Memahami dan } \\
\text { menghargai keputusan } \\
\text { orang lain, } \\
\text { bertanggung jawab } \\
\text { atas segala pilihan, } \\
\text { mengatasi masalah dan } \\
\text { hambatannya dengan } \\
\text { caranya sendiri secara } \\
\text { mandiri. } \\
\text { Minim upaya dan } \\
\text { komunikasi serta } \\
\text { penyelesaian konflik di } \\
\text { keluarga permisif } \\
\text { menumbuhkan } \\
\text { kecenderungan untuk } \\
\text { menghindari } \\
\text { penyelesaian masalah. }\end{array}$ & $\begin{array}{l}\text { Hubungan yang } \\
\text { baik dan buruk } \\
\text { dengan orang } \\
\text { lain. } \\
\text { Kemampuan } \\
\text { sosial rendah. } \\
\text { Rendahnya } \\
\text { kemampuan } \\
\text { empati dan } \\
\text { mengenali diri, } \\
\text { masalah, dan } \\
\text { situasi } \\
\text { sehingga harus } \\
\text { dibantu orang } \\
\text { lain dalam } \\
\text { mencerna } \\
\text { hikmah dari } \\
\text { pengalaman. } \\
\text { Pola asuh } \\
\text { permisif. }\end{array}$ \\
\hline $\begin{array}{c}\text { Partisipan } \\
2\end{array}$ & $\begin{array}{l}\text { Masalah Emosi: } \\
\text {-Depresif } \\
\text {-Self-blame } \\
\text {-Overthinking } \\
\text {-Suicide thoughts } \\
\text {-Ganggguan tidur } \\
\\
\text { Menarik diri sebagI } \\
\text { solusi. } \\
\text { Pemahaman dan } \\
\text { pengendalian emosi } \\
\text { sangat baik. }\end{array}$ & $\begin{array}{l}\text { Memahami diri } \\
\text { dan orang lain } \\
\text { dengan sangat } \\
\text { baik (karena } \\
\text { karakter } \\
\text { introspektif). } \\
\text { Memiliki } \\
\text { kemampuan } \\
\text { analisis masalah } \\
\text { yang sangat baik. }\end{array}$ & $\begin{array}{l}\text { Memahami dan } \\
\text { menghargai keputusan } \\
\text { orang lain, } \\
\text { bertanggung jawab } \\
\text { atas segala pilihan, } \\
\text { mengatasi masalah dan } \\
\text { hambatannya dengan } \\
\text { caranya sendiri secara } \\
\text { mandiri. } \\
\text { Minim upaya dan } \\
\text { komunikasi serta } \\
\text { penyelesaian konflik di } \\
\text { keluarga permisif } \\
\text { menumbuhkan } \\
\text { kecenderungan untuk } \\
\text { menghindari } \\
\text { penyelesaian masalah. }\end{array}$ & $\begin{array}{l}\text { Karakter } \\
\text { introspektif, } \\
\text { suka belajar, } \\
\text { dan analisis } \\
\text { masalah } \\
\text { (penyebab, } \\
\text { dampak, } \\
\text { solusi). } \\
\text { Pola asuh } \\
\text { permisif, orang } \\
\text { tua, dan } \\
\text { keluarga. } \\
\text { Pengalaman } \\
\text { buruk } \\
\text { mengenai } \\
\text { percintaan. }\end{array}$ \\
\hline
\end{tabular}




\begin{tabular}{|c|c|c|c|c|}
\hline \multirow{2}{*}{$\begin{array}{l}\text { Partisipan } \\
\text { Penelitian }\end{array}$} & \multicolumn{3}{|c|}{ Kematangan Emosi } & \multirow{2}{*}{$\begin{array}{c}\text { Faktor } \\
\text { Pendukung \& } \\
\text { Penghambat } \\
\text { Kematangan } \\
\text { Emosi }\end{array}$} \\
\hline & $\begin{array}{c}\text { Kontrol } \\
\text { Emosi }\end{array}$ & $\begin{array}{c}\text { Pemahaman } \\
\text { Diri }\end{array}$ & $\begin{array}{c}\text { Fungsi Kritis } \\
\text { Mental }\end{array}$ & \\
\hline $\begin{array}{c}\text { Partisipan } \\
3\end{array}$ & $\begin{array}{l}\text { Masalah Emosi: } \\
\text {-Amarah } \\
\text {-Tempramen buruk } \\
\text { Dulu kontrol rendah, } \\
\text { sekarang menahan } \\
\text { dan mengalihkan, } \\
\text { tapi masih sering } \\
\text { mengganggu karena } \\
\text { masih sering muncul. }\end{array}$ & $\begin{array}{l}\text { Pemahaman diri } \\
\text { banyak diperoleh } \\
\text { dari teman dan } \\
\text { diskusi, } \\
\text { Kemampuan } \\
\text { sosial dan } \\
\text { komunikasi yg } \\
\text { baik. } \\
\text { Mampu } \\
\text { membangun rasa } \\
\text { aman } \\
\text { (intrapersonal \& } \\
\text { interpersonal). }\end{array}$ & $\begin{array}{l}\text { Memahami dan } \\
\text { menghargai keputusan } \\
\text { orang lain, } \\
\text { bertanggung jawab } \\
\text { atas segala pilihan, } \\
\text { mengatasi masalah dan } \\
\text { hambatannya dengan } \\
\text { caranya sendiri secara } \\
\text { mandiri. } \\
\text { Upaya komunikasi } \\
\text { serta penyelesaian } \\
\text { konflik yang baik. }\end{array}$ & $\begin{array}{l}\text { Kemampuan } \\
\text { sosial baik dan } \\
\text { terbantu } \\
\text { teman-teman. } \\
\text { Tempramen } \\
\text { buruk. } \\
\text { Perceraian } \\
\text { orang tua. } \\
\text { Pola asuh } \\
\text { permisif. }\end{array}$ \\
\hline \multirow[t]{2}{*}{$\begin{array}{c}\text { Partisipan } \\
4\end{array}$} & $\begin{array}{l}\text { Masalah Emosi: } \\
\text {-Moodswings } \\
\text {-Kabur dari konflik } \\
\text { Mengerti solusi } \\
\text { namun keinginan } \\
\text { rendah untuk } \\
\text { menyelesaikan, } \\
\text { meninggalkan } \\
\text { masalah dan }\end{array}$ & $\begin{array}{l}\text { Pemahaman diri } \\
\text { banyak diperoleh } \\
\text { karena banyak } \\
\text { mencoba } \\
\text { pengalaman yang } \\
\text { menghasilkan } \\
\text { banyak } \\
\text { penyesalan } \\
\text { sekaligus belajar } \\
\text { sehingga }\end{array}$ & $\begin{array}{l}\text { Memahami dan } \\
\text { menghargai keputusan } \\
\text { orang lain, } \\
\text { bertanggung jawab } \\
\text { atas segala pilihan, } \\
\text { mengatasi masalah dan } \\
\text { hambatannya dengan } \\
\text { caranya sendiri secara } \\
\text { mandiri. }\end{array}$ & $\begin{array}{l}\text { Banyak } \\
\text { terbantu } \\
\text { pengalaman } \\
\text { karena banyak } \\
\text { mencoba, } \\
\text { banyak } \\
\text { kecewa, } \\
\text { banyak } \\
\text { menyesal. }\end{array}$ \\
\hline & $\begin{array}{l}\text { membuang emosi } \\
\text { sehingga masalah } \\
\text { berlarut-larut, namun } \\
\text { sekaligus membantu } \\
\text { sehingga emosi } \\
\text { negatif tidak } \\
\text { dirasakan berlarut- } \\
\text { larut. }\end{array}$ & $\begin{array}{l}\text { mengenal dirinya } \\
\text { dan solusi atas } \\
\text { masalah di masa } \\
\text { depan }\end{array}$ & $\begin{array}{l}\text { Minim upaya dan } \\
\text { komunikasi serta } \\
\text { penyelesaian konflik di } \\
\text { keluarga permisif } \\
\text { menumbuhkan } \\
\text { kecenderungan untuk } \\
\text { menghindari } \\
\text { penyelesaian masalah, }\end{array}$ & $\begin{array}{l}\text { Pola asuh } \\
\text { permisif. } \\
\text { Konflik orang } \\
\text { tua. }\end{array}$ \\
\hline
\end{tabular}

\section{I S K U S I}

Kematangan emosi merupakan keseimbangan antara emosi dengan otak serta antara dunia dalam dengan dunia luar individu (Landau, 1998). Orang tua memiliki peranan krusial dalam masa penyesuaian anak memasuki masa dewasa awal, terutama mengenai permasalahan pengelolaan emosi individu pada masa dewasa awal sebagai periode perkembangan yang unik (Kilic, dkk., 2015). Pola asuh permisif sebagai pola pengasuhan orang tua yang diterima oleh individu dewasa awal berperan masif terhadap kematangan emosi keempat partisipan yang termanifestasi dari kontrol emosi, pemahaman diri, dan penggunaan fungsi kritis mental. Pola asuh yang minim arahan, tuntutan, dan dukungan berdampak pada proses kematangan emosi individu dewasa awal. Secara umum, manifestasi INSAN Jurnal Psikologi dan Kesehatan Mental Tahun 2020, Vol. 5(1), 21-34

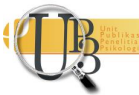


kematangan emosi yang dimiliki partisipan berbeda-beda tergantung pada faktor-faktor yang memengaruhi yaitu faktor individu, faktor lingkungan, dan faktor pengalaman yang berupa kecenderungan sifat dan karakteristik emosi, pengaruh lingkungan, maupun pengalaman dan trauma.

Kematangan emosi dapat dilihat melalui tiga dimensi, yaitu kontrol emosi, pemahaman diri, dan fungsi kritis mental (Hurlock, 2004; Murray, 1997; Walgito, 2002). Masing-masing dimensi yang mewakili manifestasi kematangan emosi terbentuk secara berbeda pada tiap individu dalam penelitian ini. Santrock (1991) menuturkan bahwa orang tua merupakan salah satu pihak yang dapat membantu anakanak dalam mengelola emosi. Pola asuh yang minim arahan, tuntutan, dan dukungan berdampak pada kondisi emosi serta pengendalian emosi partisipan. Manifestasi permasalahan emosi partisipan berupa amarah, emosi depresif, moodswings, dan overthinking. Kebebasan berekspresi yang dikembangkan orang tua membuat partisipan mengembangkan kontrol emosi yang rendah. Hal ini sejalan dengan penuturan Rahmawan (2013) bahwa pola asuh permisif menjadikan anak memiliki keleluasaan untuk mengekspresikan dirinya, termasuk segala pendapat, aktivitas, dan minat anak sementara orang tua memiliki kontrol, tuntutan, serta keterlibatan yang sangat minim sehingga turut membentuk anak menjadi pribadi dengan karakter yang tidak stabil.

Penelitian lain yang dilakukan Kilic, dkk. (2015) disebutkan bahwa sikap orang tua dalam pengasuhan memengaruhi kemampuan pengelolaan emosi individu pada masa dewasa awal. Pengalaman yang melibatkan pembelajaran emosional, baik pengalaman buruk maupun pengalaman menyenangkan, merupakan bentuk dari pembelajaran yang menjadi bagian dari proses perkembangan (Nelson, dkk., 2014). Seiring berjalannya waktu, kemampuan mengontrol emosi pada keempat subjek berubah menjadi lebih baik. Hal tersebut dikarenakan oleh beberapa faktor di mana kemampuan introspeksi dan kemauan belajar, dukungan dari lingkungan, serta pengalaman-pengalaman yang membuahkan hikmah bagi keempat partisipan. Pengendalian emosi yang masih banyak menjadi masalah adalah mereka telah mampu belajar untuk memendam dan mengenali emosinya namun dalam beberapa aspek belum mengetahui cara untuk mengatasinya sehingga permasalahan mengenai emosi masih menjadi masalah besar bagi mereka.

Barton \& Hirsch (2016) dalam penelitiannya mendapatkan hasil bahwa mahasiswa yang dibesarkan dengan pola asuh permisif mengalami stress dan memiliki kesehatan mental yang rendah. Secara umum, bentuk permasalahan emosi yang dimiliki partisipan berbeda-beda. Partisipan 1 memiliki karakteristik emosi yang mudah marah dan tersinggung serta emosi cemas depresif. Emosi-emosi negatif tersebut banyak dipicu oleh masalah dengan orang lain. Partisipan 1 memiliki kemampuan sosial yang rendah dan kemampuan merasakan empati yang juga rendah sehingga hal ini menyebabkan penyelesaian masalahnya banyak terhambat oleh masalah emosi. Salah satu masalah terbesar yang merubah hidupnya adalah pengalaman saat menghadapi dosen pembimbing skripsinya. Kemampuan mengenali masalahnya menjadi sangat terhambat dan memunculkan emosi-emosi negatif yang dalam. Pada akhirnya, permasalahan ini tertolong karena Partisipan 1 memutuskan untuk menemui psikolog dan kemudian banyak belajar dari psikolog tersebut sehingga membantunya memahami dan menghadapi emosinya. Masalah lain adalah permasalahan mengenai hubungan romantis. Emosi-emosi negatif yang dikembangkan Partisipan 1 menimbulkan rasa tidak aman terhadap dirinya dan juga terhadap orang lain. Partisipan 1 tidak mampu memahami bahwa dirinya dapat menerima cinta dari orang lain dan memiliki keyakinan bahwa ia tidak pantas untuk dicintai. Partisipan 1 pernah terlibat hubungan mutual yang saling menyukai, namun terhalang oleh ketidakmampuannya untuk percaya pada cinta. Karakteristik emosi yang dimiliki Partisipan 2 berupa emosi-emosi depresif, overthinking, hingga pemikiran bunuh diri dan masalah tidur. Partisipan 2 sangat tertutup mengenai emosinya. Sebagian besar pemicu emosi-emosi negatif yang muncul adalah rasa tidak aman terhadap dirinya sendiri dan 
masalah-masalah mengenai keluarga yang berakar dari pola asuh permisif. Cara Partisipan 2 untuk mengatasi masalah emosinya adalah dengan menarik diri.

Faktor yang banyak membantu adalah karakternya yang suka belajar, suka menganalisis segala sesuatu, serta introspeksi diri yang baik sehingga Partisipan 2 memiliki pemahaman dan pengendalian emosi yang sangat baik. Permasalahan emosi yang mendominasi pada Partisipan 3 adalah tempramen yang mudah marah. Partisipan 3 sudah lebih baik dalam mengendalikan amarah yang muncul namun menjadi cenderung menahan sehingga hal tersebut tetap membuatnya kesulitan. Faktor yang berperan besar dalam pengendalian emosinya adalah teman-temannya sebagai figur tempat berbagi dan berdiskusi. Selain itu, yang menolong Partisipan 3 untuk dapat mengatasi banyak masalahnya adalah optimisme dan kemampuan sosial yang sangat baik sehingga membantunya untuk tidak berlarut-larut dalam masalah emosinya. Pola pengasuhan Partisipan 4 yang minim arahan, tuntutan, dan dukungan sangat memengaruhi kondisi emosi dan cara penyelesaian masalahnya. Permasalahan emosi Partisipan 4 berupa tempramen yang mudah marah dan tersinggung serta kecenderungan moodswings. Hal ini masih sering terjadi dan Partisipan 4 menyikapinya dengan kabur dari masalah, menghindari masalah, dan menghindari penyelesaian masalah. Hal ini membuat masalah-masalah Partisipan 4 menjadi berlarutlarut dan terulang-ulang kembali karena ia tidak ada keinginan untuk membangun komunikasi. Namun pada aspek yang sama, hal ini membantu Partisipan 4 untuk tidak terlalu berlarut-larut pada keadaan emosi negatifnya karena kecenderungannya untuk membuang emosi. Kecenderungan ini dipengaruhi oleh pengalaman buruk yang pernah dialami dan membuat Partisipan 4 belajar untuk tidak terlalu terpaku pada emosi negatif yang disebabkan oleh kesalahan orang lain. Pada akhirnya hal ini membantu Partisipan 4 untuk tetap dapat menghadapi masalah-masalah dalam kesehariannya.

Pada aspek pemahaman diri, pola yang dikembangkan partisipan berbeda-beda. Hal tersebut disebabkan oleh perbedaan karakter yang dimiliki masing-masing partisipan. Proses pemahaman diri partisipan berkembang menjadi lebih baik karena faktor pengalaman dan lingkungan. Banyaknya pengalaman, khususnya karena luasnya kesempatan untuk mencari pengalaman akan masalah yang pernah dilalui karena faktor pola asuh, bawaan karakter akan kemampuan dan keinginan introspeksi diri, serta pengaruh orang-orang di sekitar partisipan membantu proses pencapaian pemahaman diri. Murray (1997) menjelaskan bahwa kematangan emosi adalah suatu kondisi di mana individu mencapai suatu tahap perkembangan sehingga ia mampu mengarahkan dan mengendalikan emosinya agar mendapatkan penerimaan baik oleh diri sendiri maupun orang lain. Dalam studi fungsi kognitif yang dilakukan oleh Yurgelun-Todd (2007), disebutkan bahwa ketika dewasa, kemampuan anak dalam memperhatikan informasi meningkat sehingga anak dapat mencapai tujuan sembari memiliki kendali penuh atas perilakunya.

Partisipan 1 memiliki kemampuan introspeksi dan empati yang rendah, sehingga hal tersebut menghambat proses belajarnya. Namun kemauan Partisipan 1 untuk belajar, membangun diskusi serta membuka diri terhadap orang lain membantunya berkembang. Faktor lingkungan yaitu temantemannya berperan besar dalam proses pemahaman dirinya. Pelajaran-pelajaran positif khususnya dari pengalaman yang tidak menyenangkan sulit ia dapatkan secara mandiri sehingga proses pemahaman diri Partisipan 1 terbangun melalui diskusi dan upaya-upaya untuk mendengarkan orang lain sehingga ia dapat memahami dirinya dengan lebih baik. Pada akhirnya melalui perkuliahan dan diskusi, Partisipan 1 mendapatkan pemahaman bahwa emosi-emosi negatif yang ia miliki merupakan sesuatu yang harus ia terima sebagai bagian dari dirinya sehingga Partisipan 1 belajar untuk tidak menekan emosinya. Hal ini sejalan dengan penuturan Davidoff (1991, dalam Asih \& Pratiwi, 2010) bahwa kematangan emosi merupakan kemampuan individu untuk dapat mengelola serta menyalurkan emosinya menjadi hal yang bermanfaat tanpa harus menghilangkan emosi yang ada dalam dirinya. 
Pada Partisipan 2, proses pemahaman diri banyak diperoleh dari introspeksi diri. Partisipan 2 memiliki kecenderungan tinggi untuk overthinking dan menganalisis masalah serta memiliki rasa ingin tahu yang tinggi dan kemauan besar untuk mempelajari diri dan orang lain. Hal ini merupakan faktor terbesar yang membantunya untuk dapat introspeksi diri dengan sangat baik. Pemahaman mengenai segala kecenderungan serta pengelolaan emosinya membuat Partisipan 2 memahami bahwa ia memiliki banyak perbedaan dengan orang lain sehingga ia berupaya untuk membangun pemahaman orang lain mengenai dirinya sehingga dapat meminimalisir konflik yang mungkin terjadi antara dirinya dengan orang lain. Pada akhirnya proses pemahaman diri pada Partisipan 2 tercapai dengan sangat baik terutama jika dibandingkan dengan partisipan lain.

Pemahaman diri pada Partisipan 3 banyak melalui pertemanan. Partisipan 3 memiliki kecenderungan untuk beralih pada teman dalam mengatasi sebagian besar masalahnya. Hal ini juga dipengaruhi oleh kemampuan sosial dan adaptasinya yang baik. Banyaknya diskusi dan interaksi yang dibangun oleh Partisipan 3 menjadi faktor terbesar yang memengaruhi proses pemahaman dirinya. Pada Partisipan 4, proses pemahaman diri sebagian besar didapat karena banyaknya pengalaman dan besarnya keinginan untuk mencoba berbagai macam hal. Hal ini menyebabkan Partisipan 4 banyak mengalami penyesalan sekaligus banyak belajar sehingga akhirnya ia mengenali hal-hal apa saja yang membuatnya nyaman.

Pola asuh permisif yang membebaskan anak dalam sebagian besar aspek dalam hidupnya membuat individu belajar banyak mengenai perbedaan dan rasa kecewa. Hal ini memengaruhi individu untuk memahami dan menghargai perbedaan dan keputusan orang lain. Pola asuh permisif juga memengaruhi individu untuk dapat bertanggung jawab atas segala pilihan dan mengatasi masalah dan hambatannya dengan caranya sendiri secara mandiri. Hal ini dapat memicu individu untuk mencari jalan keluar dengan caranya sendiri dan mengembangkan proses kreatifnya dalam menangani masalah. Nelson, dkk. (2014) menyebutkan bahwa pengalaman yang melibatkan pembelajaran emosional, baik pengalaman buruk maupun pengalaman menyenangkan, merupakan bentuk dari pembelajaran yang menjadi bagian dari proses perkembangan. Semiun (2006, dalam Supriyanto, 2018) menuturkan bahwa kematangan emosi juga mengacu pada kapasitas individu untuk dapat memunculkan reaksi dengan cara-cara yang lebih bermanfaat dalam menghadapi berbagai situasi kehidupan. Individu yang memiliki kematangan emosi dapat memandang suatu persoalan dengan sudut pandang yang objektif dan berpikir dengan lebih baik sehingga setiap tindakannya dapat dipertanggungjawabkan (Walgito, 2002).

Minimnya interaksi dan upaya komunikasi serta pembahasan mengenai penyelesaian konflik di keluarga permisif menumbuhkan kecenderungan individu untuk menghindari penyelesaian masalah. Bee \& Boyd (2007, dalam Rahmawan, 2013) menuturkan bahwa orang tua permisif tidak memberikan batasan, tuntutan, dan kontrol, serta penerapan komunikasi yang kurang. Hal ini menyebabkan masalah yang dimiliki individu menjadi berlarut-larut dan secara tidak langsung mengembangkan emosi-emosi negatif dalam diri individu. Secara umum pola ini terbangun senada pada keempat partisipan. Namun terdapat perbedaan pada aspek menghindari penyelesaian masalah yang diakibatkan minimnya interaksi dan pembahasan mengenai penyelesaian konflik di keluarga permisif. Partisipan 1, 2, dan 4 memiliki kecenderungan tersebut dan juga memiliki pola interaksi dan penyelesaian masalah yang minim dalam keluarganya. Namun pada Partisipan 3, ia memiliki orang tua bercerai dan menjalani interaksi yang lebih intens dengan ibunya. Meski menerapkan kebebasan serta minim hukuman dan larangan dalam pola pengasuhannnya, Ibu Partisipan 3 masih memberikan dukungan dan feedback serta menjalin komunikasi yang baik dengan Partisipan 3. Hal ini, selain juga karena faktor karakter partisipan yang senang berkomunikasi, turut memengaruhi upayanya dalam menghadapi penyelesaian masalah. 


\section{S I M P U L A N}

Pola asuh permisif sebagai pola pengasuhan orang tua yang diterima oleh individu dewasa awal berperan masif terhadap kematangan emosi individu yang termanifestasi dari kontrol emosi, pemahaman diri, dan penggunaan fungsi kritis mental. Pola asuh permisif yang diterapkan orang tua melahirkan karakter, interaksi, serta pengalaman tertentu bagi individu yang dibesarkan dengan pola asuh permisif. Pola asuh yang minim arahan, tuntutan, dan dukungan berdampak pada kondisi emosi serta pengendalian emosi individu. Dampak terhadap karakteristik emosi individu beserta segala permasalahannya menghambat proses pengenalan individu mengenai emosi dan pengendaliannya. Pola asuh permisif mengembangkan perasaan hilang arah dan pemahaman emosi yang rendah karena minimnya tuntutan, arahan, dan dukungan dari orang tua. Namun, hal ini menyebabkan anak memiliki banyak kesempatan untuk mencari pengalaman sehingga anak banyak melakukan kesalahan kemudian mendapatkan pembelajaran.

Emosi-emosi negatif yang muncul dan kemampuan kontrol emosi yang rendah pada akhirnya membuat individu dewasa banyak belajar dan memahami sehingga dapat mengelola emosinya dengan pengendalian diri. Kondisi emosi yang negatif membuat individu belajar cara mengatasi atau mengalihkan emosi tersebut. Pengalihan emosi negatif dapat berupa pengalihan negatif, pengalihan positif, maupun pengalihan yang terlihat negatif namun ternyata positif. Pengalihan negatif contohnya adalah merokok dan mengonsumsi alkohol, pengalihan positif contohnya dengan belajar atau bekerja. Sedangkan pengalihan yang tampak negatif namun ternyata positif adalah menarik diri dan tidur. Dengan memberi jeda waktu bagi diri sendiri, hal ini membantu individu menghimpun tenaga untuk dapat kembali mengatasi masalah serta emosi negatifnya.

Bagi individu yang dibesarkan dengan pola asuh permisif, pemahaman diri lebih sulit didapatkan karena sedikitnya arahan, tuntutan, hukuman, dan dukungan yang didapat dari keluarga. Hal ini mengakibatkan individu mencari tahu mengenai diri dan mengembangkan pengetahuannya dengan halhal selain keluarga. Setiap individu memiliki kecenderungan yang berbeda, sehingga proses pemahaman diri didapatkan dari faktor individu, faktor lingkungan selain keluarga, maupun faktor pengalaman. Individu yang memiliki kecenderungan introspeksi diri akan meningkatkan proses pemahaman diri melalui upaya kognitif. Individu yang memiliki kemampuan introspeksi rendah atau memiliki kemampuan sosial yang baik akan berusaha mendapatkan pemahaman dari orang-orang di sekitarnya. Sedangkan kecenderungan individu untuk mencoba berbagai macam hal akan terbantu dengan banyaknya pengalaman yang didapat, sehingga menimbulkan banyak kesalahan kemudian mendapatkan pembelajaran serta menemukan kenyamanan bagi dirinya.

Pola asuh permisif yang membebaskan anak dalam sebagian besar aspek dalam hidupnya membuat individu belajar banyak mengenai perbedaan dan rasa kecewa. Hal ini memengaruhi individu untuk memahami dan menghargai perbedaan dan keputusan orang lain. Pola asuh permisif juga memengaruhi individu untuk dapat mengatasi masalah dan hambatannya dengan caranya sendiri secara mandiri. Hal ini dapat memicu individu untuk mencari jalan keluar dengan caranya sendiri dan mengembangkan proses kreatifnya dalam menangani masalah. Namun, minimnya interaksi dan pembahasan mengenai penyelesaian konflik di keluarga permisif menumbuhkan kecenderungan individu untuk menghindari penyelesaian masalah. Hal ini menyebabkan masalah yang dimiliki individu menjadi berlarut-larut dan secara tidak langsung mengembangkan emosi-emosi negatif dalam diri individu. Permasalahan individu mengenai karakter emosi, konflik dengan keluarga maupun orang lain di sekitarnya, serta banyaknya pengalaman yang didapat memengaruhi, baik membantu maupun menghambat, keseluruhan proses pencapaian kematangan emosi individu dewasa awal dengan pola asuh permisif. 
Untuk penelitian selanjutnya, peneliti disarankan melakukan penyaringan subjek dengan lebih ketat karena informasi yang digali bersifat introspektif dan reflektif sehingga data yang didapat dapat lebih maksimal. Selain itu, masih perlu dilakukan penelitian dengan subjek yang lebih beragam secara usia, latar belakang, dan fokus tugas perkembangan. Penerapan pola asuh permisif oleh orang tua dapat dimanfaatkan anak untuk menggunakan kebebasan sebagai kesempatan mencari pengalaman sebanyak-banyaknya, mengembangkan hubungan sosial seluas-luasnya, serta bergabung dalam lingkar pertemanan dan kegiatan positif yang menyenangkan.

\section{DEKLARASI POTENSI TERJADINYA KONFLIK KEPENTINGAN}

Dina Rahma Adila \& Afif Kurniawan tidak bekerja, menjadi konsultan, memiliki saham, atau menerima dana dari perusahaan atau organisasi mana pun yang akan mengambil untung dari naskah ini, dan telah mengungkapkan bahwa ia tidak memiliki afiliasi selain yang telah disebut di atas.

\section{P USTAKA ACUAN}

Anisah, A. S. (2017). Pola Asuh Orang Tua dan Implikasinya Terhadap Pembentukan Karakter Anak. Jurnal Pendidikan UNIGA, 5(1), 70-84.

Asih, G. Y., \& Pratiwi, M. M. (2010). Perilaku prososial ditinjau dari empati dan kematangan emosi. Jurnal Psikologi UMK: PITUTUR, 1(1), 33-42.

Astuti, H. (2000). Psikologi Perkembangan Masa Dewasa. Surabaya: Usaha Nasional.

Barton, A. L., \& Hirsch, J. K. (2016). Permissive parenting and mental health in college students mediating effects of academic entitlement. Journal of American college Health, 64(1), 1-8.

Baumrind, D. (1991). The Influence of Parenting Style on Adolescent Competence and Substance Use. The Journal of Early Adolescence, 11(1), 56-95.

Boyatzis, R. (1998). Transforming Qualitative Information: Thematic Analysis and Code Development. California: Sage Inc.

Creswell, J. W. (2007). Qualitative Inquiry \& Research Design: Choosing among Five Approach (2nd ed.). California: Sage Inc.

Hurlock, E. B. (1999). Remaja Berkualitas: Problematika Remaja dan Solusinya. Jakarta: Erlangga.

Hurlock, E. B. (2004). Psikologi Perkembangan: Suatu Perkembangan Sepanjang Rentang Kehidupan. Jakarta: Erlangga.

Khairani, R., \& Putri, D. E. (2011). Kematangan emosi pada pria dan wanita yang menikah muda. Jurnal Ilmiah Psikologi, 1(2).

Kilic, S., Var, E. C., \& Kumandas, H. (2015). Effect of Parental Attitudes on Skills of Emotional Management in Young Adults. Procedia - Social and Behavioral Sciences, 191, 930-934.

Kuwabara, S. A., Van Voorhees, B. W., Gollan, J. K., \& Alexander, G. C. (2007). A Qualitative Exploration of Depression in Emerging Adulthood: Disorder, Development, and Social Context. General Hospital Psychiatry, 29(4), 317-324.

INSAN Jurnal Psikologi dan Kesehatan Mental

Tahun 2020, Vol. 5(1), 21-34

doi: 10.20473/jpkm.v5i12020.21-34 
Landau, E. (1998). The Self - The Global Factor of Emotional Maturity. Roeper Review, 20(3), 174-178.

Murray, J. (1997). Are You Growing Up, Or Just Getting Older? Diakses pada tanggal 4 Februari 2019 dari http://www.sonic.net/ drmurray/maturity.htm.

Nelson, E. E., Lau, J. Y., \& Jarcho, J. M. (2014). Growing Pains And Pleasures: How Emotional Learning Guides Development. Trends in Cognitive Sciences, 18(2), 99-108.

Poerwandari, E. (2007). Pendekatan Kualitatif untuk Penelitian Perilaku Manusia. Depok: Lembaga Pengembangan Sarana Pengukuran dan Pendidikan Psikologi Universitas Indonesia (LPSP3).

Rahmawan, I. A. (2013). Hubungan Antara Pola Asuh Permisif dengan Intensi Bullying pada Siswa-Siswi Kelas Vlll SMP Muhammadiyah 4 Yogyakarta. EMPATHY Jurnal Fakultas Psikologi, 2(1).

Rakhmawati, I. (2015). Peran Keluarga dalam Pengasuhan Anak. Bimbingan Konseling Islam, 6, 1-18.

Santrock, J. W. (1991). Psychology: The Science Of Mind and Behavior. Dubuque: WCB Publishers.

Santrock, J. W. (2010). Educational Psychology (5th ed.). New York: McGraw-Hill.

Schilling, E. A., Aseltine, R. H., \& Gore, S. (2007). Adverse Childhood Experiences and Mental Health in Young Adults A Longitudinal Survey. BMC Public Health, 7(1).

Shulman, S., Feldman, B., Blatt, S., Cohen, O., \& Mahler, A. (2005). Emerging Adulthood. Journal of Adolescent Research, 20(5), 577-603.

Supriyanto, E. (2018). Hubungan Kematangan Emosi dan Agresivitas Pada Pemain Sepakbola Remaja Akhir. Jurnal Ilmiah Psikologi, 10(2).

Walgito, B. (2002). Bimbingan dan Konseling Perkawinan. Yogyakarta: Penerbit Andi.

Yin, R. K. (2011). Qualitative Research from Start to Finish. New York: The Guilford Press.

Yurgelun-Todd, D. (2007). Emotional and Cognitive Changes During Adolescence. Current Opinion in Neurobiology, 17(2), 251-257.

Yusuf, S. (2001). Psikologi Perkembangan Anak dan Remaja. Bandung: PT Remaja Resdakarya. 